\title{
Susceptibility of six cotton varieties and genotypes to infestation by the pink bollworm, Pectinophora gossypiella (Saund.) in Kafr El-Sheikh governorate, Egypt
}

\author{
Somaa, H.M.H. and Zayed, G.M.M.
}

\author{
Plant Protection Research Institute, Agric. Res. Center, Egypt.
}

\begin{abstract}
A`bstract
Trials were carried out during 2012 and 2013 cotton seasons at Sakha Agricultural Research Station Farm, Kafr El-Sheikh governorate, Egypt to evaluate the efficiency of six cotton varieties and genotypes on infestation by pink bollworm, Pectinophora gossypiella (Saund.) throughout the season. Results during the two experiments showed that infestation \% of PBW to six cotton varieties and genotypes in both seasons were $(14.90,9.82,21.56,10.54,10.66$ and 13.34\%) for Giza 86, Pima S6 x. Giza 77, Giza 92, Giza 94, Giza 86 x $10 / 229$ and Giza 88, respectively.

The higher means of infestation \% were recorded in the G.92, G.86 and G.88 in both seasons, while the lower means of infestation \% were recorded in the Pima S6 x G.77 and G.94 in both seasons. The differences among means of infestation \% may be due to the differences in gossypol \% in wall and wall thickness of green bolls. The means of gossypol \% in green boll wall were $(1.78,1.32,1.44,0.91,1.75$ and $1.16 \%)$ and the means of wall thickness were $(2.77,2.38,2.07,2.82,3.04$ and $2.94 \mathrm{~mm})$ for above mentioned cotton varieties and genotypes during both seasons, respectively. There were highly significant differences among the cotton varieties and genotypes in some characters.
\end{abstract}

Key Words: Pectinophora gossypiella, cotton varieties and genotypes, Gossypol, wall thickness of bolls

\section{Introduction}

Pink bollworm is one of the most important pests of cotton and other crops in Egypt. This pest attacks the fruit bodies of cotton and cause heavy losses in the yield. So far, the main method of controlling pink bollworm on cotton has been the use of insecticides. Chemical control of this insect is expensive and serious peripheral problems have emerged, those include the development of insecticide-resistant insect strains, reduction of pest insect natural enemies, resurgence of pest populations in the absence of natural enemies, occurrence of secondary pests and environmental contamination. Therefore, it is strictly necessary to select resistant varieties as one of the simplest and useful tactics in integrated pest management programmes. Differences in the susceptibility of cotton varieties to pink bollworm infestation have been previously studied by (Hassanein et al., 1969; Abd El-Rahim et al. (1976); Abdel-Bary et al., 1980; Abdel-Halim et al., 2000; El-Mezayyen, 2004 and Al-Ameer et al., 2010). Therefore, the present study was initiated to determine the relative susceptibility of six cotton varieties and genotypes to infestation by $P$. gossypiella under field agro-conditions.

\section{Materials and Methods}

Six Egyptian cotton varieties and genotypes were selected for this study namely: Giza 86, Pima S6 x Giza 77, Giza 92, Giza 94, Giza 86 x 10/229 and Giza 88. This experiment was conducted at Sakha
Agricultural Research Station, Kafr El-Sheikh Governorate during 2012 and 2013 seasons.

Plot size measured $42 \mathrm{~m}^{2}$ (1/100 feddan) with three replicates for each variety and genotype arranged in a complete randomized block design. Therefore, the experimental field contained 18 plots. Cotton was sown on March $29^{\text {th }} 2012$ and March $20^{\text {th }}, 2013$, adopting the normal agricultural practices of irrigation and fertilization including three recommended insecticidal treatments as follows:

$1^{\text {st }}$ treatment: Applied in July with Sylian $72 \%$ EC (0-4-bromo-2-chlorophenyl-O-ethyl-S-propyl

phosphorothioate) (at rate of $750 \mathrm{~cm}^{3} /$ feddan) and Dimeuron 10\% EC, 1-[3,5-dichloro-4-(1,1,2,2-tetra fluoroethoxy) phenyl]-3-(2,6-difluorobenzoyl) urea, at rate of $200 \mathrm{~cm}^{3} /$ feddan, $2^{\text {nd }}$ treatment: in July and August (two weeks after the $1^{\text {st }}$ treatment) with Killeforon 5\% EC (RS)-1-[2,5-dichloro-4-(1,1,2,3,3,3hexafluoroproxy) phenyl]3-(2,6-difluorobenzoyl), urea (at rate of $160 \mathrm{~cm}^{3} /$ feddan), and Cyperco $20 \%$ EC (RS)-a-cyano-3-phenoxyl (1RS-3 RS, 1RS-3SR)-3(2,2-dichlorovinyl) 2,2-dimethyl cyclopropane carboxylate, (at rate of $150 \mathrm{~cm} /$ feddan), and $3^{\text {rd }}$ treatment: in August and September with Sylian $72 \%$ EC and Dimeuron $10 \%$ EC. Every insecticide was sprayed at 2 week intervals starting from July using the recommended rate of the proper insecticide diluted with 400 liters water. All sprays were conducted using knapsack sprayer (CP3 model). Weekly random samples of 50 green bolls were collected from each plot (150 green bolls/each variety) and kept in tightly closed polyethylene bags, then dissected and examined in the laboratory of Plant Protection 
Research Institute at Sakha, Kafr El-Sheikh from the second week of July until the second week of October. Percentages of infestation by pink bollworm were determined in each cotton variety and genotype. So, cotton yield $\mathrm{g} / \mathrm{m}^{2}$ of each variety and genotype was evaluated. 40 bolls were picked from each variety as samples for estimating gossypol ratio in green boll wall chemical analysis took place in the laboratory of Chemical Research Department, Cotton Research Institute at Giza. The actual measurement of green boll wall thickness in millimeters was done as the distance across the fertile lemma and palea at the widest point (IRRI Stand, 1996). The statistical analysis was conducted using the software programme MSTATC.

\section{Results and Discussion}

Infestation rates by Pectinophora gossypiella in the season 2012:

Results in Table (1) show the mean numbers of infested green bolls by PBW larvae per 50 bolls for each of six varieties and genotypes of cotton, seasonal mean numbers of infested bolls were (6.50, $6.50,12.63,7.08,4.58$ and 8.42 bolls) for G.86, Pima S6 x G.77, G.92, G.94, G.86 x 10/229 and G.88, respectively.

The higher mean numbers of infestation bolls during this season were estimated in G.92 and G.88 (12.63 and 8.42 bolls), respectively. While, the lower were in G.86 x 10/229, Pima S6 x G.77 and G.86 $(4.58,6.50$ and 6.50 bolls), respectively.

Table 1. Weekly mean numbers of infested green cotton bolls by $P$. gossypiella per 50 green bolls during season 2012.

\begin{tabular}{ccccccc}
\hline Variety & G.86 & Pima S6 x G.77 & G.92 & G.94 & G.86 x 10/229 & G.88 \\
Date & & & & & & \\
\hline $26 / 7$ & 0 & 0 & 0 & 0 & 0 & 0 \\
$2 / 8$ & 0 & 2 & 0 & 1 & 0 & 2 \\
$9 / 8$ & 1 & 1 & 0 & 0 & 1 & 0 \\
$16 / 8$ & 0 & 0 & 0 & 0 & 0 & 0 \\
$23 / 8$ & 0 & 0 & 0 & 0 & 0 & 1 \\
$30 / 8$ & 1 & 0 & 0 & 0 & 1 & 2 \\
$6 / 9$ & 2 & 3 & 2 & 2 & 4 & 6 \\
$13 / 9$ & 2 & 3 & 2 & 2 & 2 & 14 \\
$20 / 9$ & 3 & 4 & 3 & 5 & 3 & 13 \\
$27 / 9$ & 9 & 7 & 5 & 5 & 4 & 11 \\
$4 / 10$ & 11 & 8 & 10 & 16 & 8 & 21 \\
$11 / 10$ & 10 & 7 & 7 & 11 & 5 & 12 \\
$18 / 10$ & 15 & 9 & 22 & 21 & 15 & 28 \\
$25 / 10$ & 24 & 41 & 50 & 29 & 55 & 8.42 \\
Total & 78 & 85 & 101 & 92 & 4.58 & \\
G.m. & 6.50 & 6.50 & 12.63 & 7.08 & & \\
\hline
\end{tabular}

\section{Inspections of season 2013:}

Data presented in Table (2) indicate that the mean numbers of infested bolls by PBW larvae in season 2013, were $(8.40,3.31,8.92,3.46,6.08$ and 4.92 bolls) for the same varieties and genotypes, respectively. The higher mean numbers of infested bolls during this season were estimated in G.92 and G.86 (8.92 and 8.40 bolls), respectively. While, the low was in Pima S6 x G.77 and G.94 (3.31 and 3.46 bolls), respectively.

General means of infested green bolls from six varieties and genotypes of cotton during both seasons:

In both seasons (2012 and 2013), data in Table (3) show that the general means of infestation rates were $(14.90,9.82,21.56,10.54,10.66$ and 13.34\%). The highest and lowest average means of data over both seasons (21.56 and $14.90 \%)$ and (9.82 and $10.54 \%)$ for (G.92 and G.86) and (Pima S6 x G.77 and G.94), respectively. Data in Table (4) indicate the significant differences among varieties and genotypes $\left(27.15^{* *}\right)$ and insignificant differences between years $\left(40.61^{\mathrm{NS}}\right)$, but between varieties and years was significant differences $\left(28.27^{* *}\right)$. Many authors found differences between varieties and genotypes. They found that the early bloomer varieties were most resistant for infestation by PBW larvae such as (G.76, G.89, G.80, G.31), while (late bloomer varieties and genotypes) were the most susceptible such as (G.45, Bahtim 101, G.85, G.88, G.75 and G.70) (Hassanein et al., 1969; AbdEl-Rahim et al., 1976; Abdel-Bary et al., 1980; Abou Toor et al., 1989; Abdel-Halim et al., 2000; Shawer, 2000 and El-Mezayyen, 2004). Also, AlAmeer et al. (2010) found that Karshensky2 and G.70 (late bloomer) were most susceptible varieties, while Pima S6 x G.89 and Seuvin (early bloomer variety) were the most resistant during 2007 and 2008 seasons at Kafr El-Sheikh region. 
Table 2. Weekly mean numbers of infested green bolls by pink bollworm P. gossypiella (Saund.) per 50 green bolls during season 2013.

\begin{tabular}{|c|c|c|c|c|c|c|c|}
\hline Date & Variety & G.86 & Pima S6 x G.77 & G.92 & G.94 & G.86 x 10/229 & G.88 \\
\hline $25 / 7$ & & 0 & 0 & 0 & 0 & 0 & 0 \\
\hline $1 / 8$ & & 0 & 2 & 0 & 4 & 2 & 2 \\
\hline $8 / 8$ & & 0 & 4 & 6 & 6 & 4 & 0 \\
\hline $15 / 8$ & & 0 & 0 & 0 & 0 & 0 & 0 \\
\hline $22 / 8$ & & 3 & 1 & 1 & 2 & 1 & 0 \\
\hline $29 / 8$ & & 4 & 3 & 3 & 3 & 1 & 3 \\
\hline $5 / 9$ & & 2 & 1 & 1 & 0 & 0 & 0 \\
\hline $12 / 9$ & & 2 & 1 & 1 & 1 & 0 & 1 \\
\hline $19 / 9$ & & 2 & 3 & 1 & 1 & 1 & 2 \\
\hline $26 / 9$ & & 6 & 2 & 3 & 2 & 5 & 4 \\
\hline $3 / 10$ & & 5 & 2 & 7 & 2 & 5 & 4 \\
\hline $10 / 10$ & & 10 & 4 & 14 & 4 & 10 & 8 \\
\hline $17 / 10$ & & 20 & 8 & 28 & 8 & 20 & 16 \\
\hline $24 / 10$ & & 30 & 12 & 42 & 12 & 30 & 24 \\
\hline Total & & 84 & 43 & 107 & 45 & 79 & 64 \\
\hline G.m & & 8.40 & 3.31 & 8.92 & 3.46 & 6.08 & 4.92 \\
\hline
\end{tabular}

Gossypol concentration in green boll wall:

\section{Inspections during season 2012:}

Results in Table (3) show that the means of gossypol in green boll wall of varieties and genotypes of cotton were $(1.78,1.33,1.44,0.88,1.75$ and $1.16 \%$ ) for G.86, Pima S6 x G.77, G.92, G.94, G.86 x 10/229 and G.88, respectively. The highest average of gossypol \% during 2012 season was estimated in G.86 and G.86x 10/229 (1.78 and $1.75 \%$ ), respectively. While, the lowest was in G.94 and G.88 (0.88 and $1.16 \%)$, respectively.

\section{Inspections season 2013:}

Data presented in Table (3) indicate that the means of gossypol \% in green boll wall in season 2013 were $(1.77,1.31,1.43,0.93,1.74$ and $1.15 \%)$ for the same varieties and genotypes of cotton, respectively. The highest average of gossypol \% during this season was estimated in G.86 and G.86 x $10 / 229$ (1.77 and $1.74 \%$ ), respectively. While, the lowest was in G.94 and G.88 (0.93 and 1.15\%), respectively.

\section{Gossypol \% from mean data during both seasons:}

In both seasons (2012 and 2013) the averages of gossypol \% as shown in Table (3) were $(1.78,1.32$, $1.44,0.91,1.75$ and $1.16 \%)$. The highest and lowest averages of gossypol \% during the two both seasons, (1.78 and $1.75 \%)$ and $(0.91$ and $1.16 \%)$ for (G.86 and G.86 $\mathrm{x}$ 10/229) and (G.94 and G.88), respectively. Previous results mean that infestation of green bolls, correlated with gossypol\%, so it showed that cotton varieties and genotypes of higher gossypol \% were of lower infestation rate by PBW larvae. While, varieties and genotypes of low gossypol \% had the highest infestation rates by PBW larvae.

Results in Table (4) showed significant differences between varieties $\left(0.685^{* *}\right)$, but those were non-significant between years $\left(0.001^{\mathrm{NS}}\right)$ and between (varieties and years) was $\left(0.001^{\mathrm{NS}}\right)$.

Data in Table (5) show that the correlation coefficient was negative and significant between infestation of green bolls and concentration of gossypol (-0.978*). 
Table 3. Mean performance of varieties and genotypes of cotton under two years and their mean for six traits.

\begin{tabular}{|c|c|c|c|c|c|c|c|c|c|c|c|c|c|c|c|}
\hline \multirow[t]{2}{*}{ Varieties } & \multicolumn{3}{|c|}{ Infestation $\%$} & \multicolumn{3}{|c|}{ Gossypol \% } & \multicolumn{3}{|c|}{ Boll wall thickness (mm) } & \multicolumn{3}{|c|}{ Weight of bolls (g) } & \multicolumn{3}{|c|}{ Yield $(\mathrm{g})$} \\
\hline & 2012 & 2013 & Mean & 2012 & 2013 & Mean & 2012 & 2013 & Mean & 2012 & 2013 & Mean & 2012 & 2013 & Mean \\
\hline G.86 & $13.00 \mathrm{~d}$ & $16.80 \mathrm{a}$ & $14.90 \mathrm{~b}$ & $1.78 \mathrm{a}$ & $1.77 \mathrm{a}$ & $1.78 \mathrm{a}$ & $2.75 \mathrm{ab}$ & $2.78 \mathrm{a}$ & $2.77 \mathrm{~b}$ & $13.81 \mathrm{~cd}$ & $13.22 \mathrm{ab}$ & $13.52 \mathrm{bc}$ & $825.00 \mathrm{a}$ & $303.33 \mathrm{bc}$ & $564.17 \mathrm{bc}$ \\
\hline Pima S6xG.77 & $13.00 \mathrm{~d}$ & $6.62 \mathrm{~d}$ & $9.82 \mathrm{de}$ & $1.33 \mathrm{~b}$ & $1.31 \mathrm{bc}$ & $1.32 \mathrm{c}$ & $2.37 \mathrm{~b} \mathrm{c}$ & $2.38 \mathrm{~b}$ & $2.38 \mathrm{c}$ & $13.66 \mathrm{~cd}$ & $13.68 \mathrm{ab}$ & $13.67 \mathrm{~b}$ & $460.00 \mathrm{c}$ & $445.00 \mathrm{ab}$ & $452.50 \mathrm{~d}$ \\
\hline G.92 & $25.25 \mathrm{a}$ & $17.84 \mathrm{a}$ & $21.56 \mathrm{a}$ & $1.44 \mathrm{~b}$ & $1.43 \mathrm{~b}$ & $1.44 \mathrm{~b}$ & $2.08 \mathrm{c}$ & $2.05 \mathrm{c}$ & $2.07 \mathrm{~d}$ & $14.07 \mathrm{c}$ & $12.25 \mathrm{c}$ & $13.16 \mathrm{bc}$ & $910.00 \mathrm{a}$ & 363.33 & $636.67 \mathrm{ab}$ \\
\hline G.94 & $14.16 \mathrm{c}$ & $6.92 \mathrm{~d}$ & $10.54 \mathrm{~d}$ & $0.88 \mathrm{~d}$ & $0.93 \mathrm{~d}$ & $0.91 \mathrm{e}$ & $2.83 \mathrm{a}$ & $2.81 \mathrm{a}$ & $2.82 \mathrm{ab}$ & $15.59 \mathrm{~b}$ & $12.29 \mathrm{c}$ & $13.94 \mathrm{~b}$ & $800.00 \mathrm{a}$ & $a b c$ & $508.34 \mathrm{~cd}$ \\
\hline G. $86 \times 10 / 229$ & $9.16 \mathrm{e}$ & $12.16 \mathrm{~b}$ & $10.66 \mathrm{~d}$ & $1.75 \mathrm{a}$ & $1.74 \mathrm{a}$ & $1.75 \mathrm{a}$ & $3.02 \mathrm{a}$ & $3.06 \mathrm{a}$ & $3.04 \mathrm{a}$ & $17.50 \mathrm{a}$ & $14.83 \mathrm{a}$ & $16.17 \mathrm{a}$ & $920.00 \mathrm{a}$ & $216.67 \mathrm{c}$ & $716.67 \mathrm{a}$ \\
\hline G.88 & $16.84 \mathrm{~b}$ & $9.84 \mathrm{c}$ & $13.34 \mathrm{c}$ & $1.16 \mathrm{c}$ & $1.15 \mathrm{c}$ & $1.16 \mathrm{~d}$ & $2.82 \mathrm{a}$ & $3.06 \mathrm{a}$ & $2.94 \mathrm{a} \mathrm{b}$ & $12.87 \mathrm{~d}$ & $11.74 \mathrm{c}$ & $12.31 \mathrm{~d}$ & $675.00 \mathrm{~b}$ & $\begin{array}{l}513.33 \mathrm{a} \\
215.00 \mathrm{c}\end{array}$ & $445.00 \mathrm{~d}$ \\
\hline Grand mean & 15.24 & 11.70 & 13.47 & 1.39 & 1.39 & 1.39 & 2.65 & 2.69 & 2.67 & 14.58 & 13.00 & 13.80 & 765.00 & 342.78 & 553.89 \\
\hline LSD 0.05 & 1.06 & 1.30 & 0.77 & 0.11 & 0.16 & 0.09 & 0.42 & 0.29 & 0.24 & 0.97 & 0.83 & 0.60 & 122.00 & 188.00 & 104.85 \\
\hline
\end{tabular}

Table 4. Mean squares of years, varieties and genotypes of cotton and their interaction for six traits.

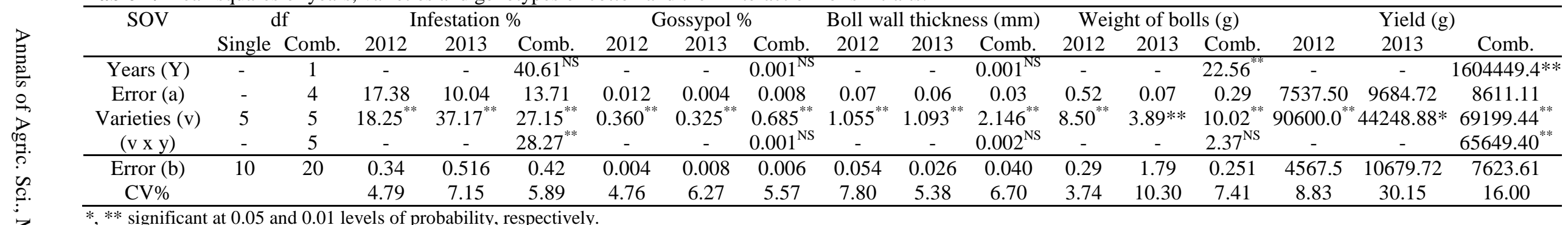


Table 5. The correlation coefficients values among all studied characters:

\begin{tabular}{lccccc} 
Traits & Infestation \% & $\begin{array}{c}\text { Gossypol } \\
\%\end{array}$ & $\begin{array}{c}\text { Boll wall thickness } \\
(\mathrm{mm})\end{array}$ & $\begin{array}{c}\text { Weight of bolls } \\
(\mathrm{g})\end{array}$ & Yield (g) \\
\hline $\begin{array}{l}\text { Infestation } \\
\%\end{array}$ & - & $-0.978^{*}$ & $-0.485^{* *}$ & $-0.045^{\mathrm{NS}}$ & $-0.263^{\mathrm{NS}}$ \\
$\begin{array}{l}\text { Gossypol } \\
\%\end{array}$ & - & $-0.466^{* *}$ & $0.307^{\mathrm{NS}}$ & $0.222^{\mathrm{NS}}$ \\
$\begin{array}{l}\text { Boll wall thickness } \\
(\mathrm{mm})\end{array}$ & & - & $0.194^{\mathrm{NS}}$ & $-0.129^{\mathrm{NS}}$ \\
\hline $\begin{array}{l}\text { Weight of bolls }(\mathrm{g}) \\
\text { Yield }(\mathrm{g})\end{array}$ & & & - & $0.613^{* *}$ \\
\hline
\end{tabular}

The obtained results agree with Al-Ameer et al. (2010) who found that the correlation between concentration of gossypol and insect infestation was significantly negative $\left(-0.551^{*}\right)$. Also, Abou-Toor (1986) estimated that the correlation was negative and significant between resistance to bollworms infestation and number of glands $/ \mathrm{cm}^{2}$ of boll and total gossypol contents. According to Bottger (1964) gossypol is also toxic to cotton bollworm, furthermore Shaver and Lukefahr (1969) showed the effect of gossypol (concentration) on bollworms and budworms. Also, Vilkova (1989) reported that even though high gossypol lines had weight when compared to those on low gossypol lines, the larval from the high gossypol lines that survived had a higher pupal weight because of their apparent resistance to gossypol, but fecundity of these survivors was significantly reduced. Abd El-Hamid and Helw (1973) and Meisner et al. (1977) suggested that gossypol content may be one of the factors associated with resistance to cotton leaf worm, so these genotypes can be used as a stock in breeding programs or using in the direct and general agriculture.

\section{Green boll wall thickness (mm): \\ Inspections of season 2012}

Results in Table (3) show that the means of green boll wall thickness of 6 varieties and genotypes of cotton, were $(2.75,2.37,2.08,2.83,3.02$ and 2.82 $\mathrm{mm}$ ) for G.86, Pima S6 x G.77, G.92, G.94, G.86 x $10 / 229$ and G.88, respectively. The higher means of green boll wall thickness during this season were estimated in G.86 x 10/229 and G.94 (3.02 and 2.83 $\mathrm{mm})$, respectively. While, the lower were in G.92 and Pima S6 x G.77 (2.08 and $2.37 \mathrm{~mm})$, respectively.

\section{Inspections of season 2013:}

Data presented in Table (3) indicate that the means of green boll wall thickness were $(2.78,2.38$, $2.05,2.81,3.06$ and $3.06 \mathrm{~mm}$ ) for the same varieties and genotypes of cotton, respectively. The higher means of green boll wall thickness were estimated in G.86 x 10/229 and G.88 (3.06 and $3.06 \mathrm{~mm}$ ), respectively. While, the lower were in G.92 and Pima S6 x G.77 (2.05 and $2.38 \mathrm{~mm}$ ), respectively.

\section{Green boll wall thickness from mean data during both seasons:}

In both seasons (2012 and 2013), the green boll wall thickness from mean data (Table 3$)$ were (2.77, $2.38,2.07,2.82,3.04$ and $2.94 \mathrm{~mm})$. The highest and lowest means of green boll wall thickness from two seasons data were (3.04 and $2.94 \mathrm{~mm})$ and $(2.07$ and $2.38 \mathrm{~mm}$ ) for (G.86 x 10/229 and G.88) and (G.92 and Pima S6 x G.77), respectively. Results in Table (4) reveal that the significant difference among varieties was $\left(2.146^{* *}\right)$, but differences were nonsignificant between years $\left(0.001^{\mathrm{NS}}\right)$ and between (varieties and years) $\left(0.002^{\mathrm{NS}}\right)$. Also, data in Table (5) show that the correlation coefficient values were negatively significant $\left(-0.485^{* *}\right)$ between infestation of green boll by larvae PBW and green boll wall thickness.

\section{Boll weight (g):}

\section{Inspections of season 2012 :}

Results in Table (3) show the means of boll weight of 6 varieties and genotypes of cotton were $(13.81,13.66,14.07,15.59,17.50$ and $12.87 \mathrm{~g})$ for G.86, Pima S6 x G.77, G.92, G.94, G.86 x 10/229 and, G.88 respectively. The higher means of boll weight were estimated in G.86 x 10/229 and G.94 (17.50and $15.59 \mathrm{~g})$, respectively. While, the lower ones were in G.88 and Pima S6 x G.77 (12.87 and $13.66 \mathrm{~g})$, respectively.

\section{Inspections of season 2013:}

The data presented in Table (3) indicated that the means of boll weight, were $(13.22,13.68,12.25$, $12.29,14.83$ and $11.74 \mathrm{~g}$ ) for the same varieties and genotypes of cotton, respectively. The highest means of boll weight were estimated in G.86 x 10/229 and Pima S6 x G.77 (14.83 and 13.68 g), respectively. While, the lowest ones were in G.88 and G.92 (11.74 and $12.25 \mathrm{~g}$ ), respectively.

Boll weight from mean data during both seasons:

In both seasons (2012 and 2013), the boll weights from mean data (Table 3), were $(13.52,13.67,13.16$, $13.94,16.17$ and $12.31 \mathrm{~g})$. The highest and lowest averages of boll weight were (16.17 and $13.94 \mathrm{~g})$ and (12.31 and 13.16g) for (G.86 x 10/229 and G.94) and(G.88 and G.92), respectively. The results 
presented in Table (4) showed significant differences among varieties $(10.02 * *)$, and also between years $\left(22.56^{* *}\right)$, but those were non-significant between years and varieties $\left(2.37^{\mathrm{NS}}\right)$. Previous results in Table (5) showed that correlation coefficient values were negatively non-significant $\left(-0.045^{\mathrm{NS}}\right)$ between infestation rate to green bolls and boll weight.

\section{Yield $/ \mathrm{m}^{2}$ of cotton varieties and genotypes: \\ Inspections of season 2012:}

Means of yield of 6 cotton varieties and genotypes of cotton were $(825,460,910,800,920$ and $675 \mathrm{~g}$ ) for G.86, Pima S6 x G.77, G.92, G.94, G.86 x 10/229 and G.88, respectively (Table 3). The highest means of yield were estimated in G.86 x 10/229 and G.92 (920 and $910 \mathrm{~g}$ ), respectively, while, the lowest were in Pima S6 x G.77 and G.88 (460 and $675 \mathrm{~g}$ ), respectively.

\section{Inspections of season 2013:}

The data presented in Table (3) indicate that the means of yield, were $(303.33,445.00,363.33$, $216.67,513.33$ and $215.00 \mathrm{~g}$ ) for the same varieties and genotypes of cotton, respectively. The highest means of yield during this season was estimated in G.86 x 10/229 and Pima S6 x G.77 (513.33 and $445.00 \mathrm{~g})$, respectively, while, the lowest were in G.88 and G.94 (215.00 and $216.67 \mathrm{~g}$ ), respectively.

Two season means of cotton yield $/ \mathrm{m}^{2}$ from different varieties and genotypes:

In both seasons (2012 and 2013), the means of yield $/ \mathrm{m}^{2}$ were $(564.17,452.50,636.67,508.34$, 716.67 and $\left.445.00 \mathrm{~g} / \mathrm{m}^{2}\right)$. The higher and lower averages were $\left(716.67\right.$ and $\left.636.67 \mathrm{~g} / \mathrm{m}^{2}\right)$ and $(445.00$ and $452.50 \mathrm{~g} / \mathrm{m}^{2}$ ) for (G.86 x 10/229 and G.92) and (G.88 and Pima S6 x G.77), respectively. Data in Table (5), the coefficient value was negative nonsignificant $\left(-0.263^{\mathrm{NS}}\right)$ between infestation of green bolls and yield $/ \mathrm{m}^{2}$. But Al-Ameer et al. (2010) found the value of correlation was negatively nonsignificant between infestation and lint yield $/ \mathrm{m}^{2}$ ($0.684 *)$.

\section{References}

Abdel-Bary, A.A.; M.A. Omer and M.M. Shahbander (1980). Evaluation of bollworm resistance in some Egyptian cotton cultivars and strains. Alex. J. Agric. Res., 28(1): 91-96.

Abdel-Halim, A.; K.A.M. El-Khawass and H.A.F. Salem (2000). Boll infestations with pink bollworm (Pectinophora gossypiella) and spiny bollworm (Earias insulana) on certain cotton varieties in Damietta Governorate. Al-Azhar J. Agric. Res., 31: 149-155.
Abdel-Hamid, A.M. and M.R. Helw (1973). Cotton leafworm on different genotypes of cotton. Cott. Gr. Rev., 50(4): 338.

Abd El-Rahim, W.A.; S.M.I. Metwally and F. ElDakroury (1976). Susceptibility of some Egyptian cotton varieties to the infestation by Pectinophora gossypiella (Saund.) and Earias insulana (Boisd.). J. Agric. Res.. Tanta Univ., 2(2): 332-338.

Abou Toor, H.B. (1986). Genetical studies on resistance to insects in Egyptian cotton. Ph.D. Thesis, Fac. Agric., Tanta Univ. 210 pp.

Abou Toor, H.B.; M.M. Abou-Kahla; A.A.S. ElZanan and I.A.I. Helal (1989). The susceptibility of nine Egyptian cotton cultivars to infestation with cotton insect pests. The $7^{\text {th }} \mathrm{Arab}$ Pesticide Conference, Tanta Univ., Sept. 11-12.

Al-Ameer, M.A.; M.A. Abd El-Salam; W.M.B. Yehia and I.A.I. Saad (2010). Evaluation of some cotton genotypes for ability to infestation tolerance to bollworm for improving of some important economical characters. J. Agric. Res. Kafr El-Sheikh Univ., 36(2): 147-172.

Bottger, G.T. (1964). Relation of gossypol content of cotton plants to insect resistance. J. Econ. Entomol., 57: 283-285.

El-Mezayyen, G.A. (2004). Evaluation of some Egyptian cotton varieties to infestation of piercing sucking insects, cotton leafworm and bollworms at Kafr El-Sheikh region. J. Agric. Sci. Mansoura Univ., 29(1): 433-441.

Hassanein, M.H.; M. Hafez and G.A. Rizk (1969). The susceptibility of certain cotton varieties to bollworms infestation. Bull. Soc. Ent. Egypte, 53: 261-269.

IRRI (1996) Standard evaluation system for rice INGER Prog. International Rice Research Institute July Edition p. 12, 13, 43, 47.

Meisner, J.; M. Zur; E. Kabonci and K.R.S. Ascher (1977). Influence of gossypol content of leaves of different cotton strains on the development of Spodoptera littoralis larvae. J. Econ. Entomol., 70(6): 714-716.

Shaver, T.N. and M.J. Lukefahr (1969). Effects of flavonoids pigments and gossypol on growth and development of the bollworm, tobacco budworm, and pink bollworm. J. Econ. Entomol., 62: 643646.

Shawer, D.M.B. (2000). Ecological studies on some insect pests infesting cotton plants. M.Sc. Thesis, Fac. Agric., Kafr El-Sheikh, Tanta Univ. 160 pp.

Vilkova, N.A. (1989). Effect of cotton cultivars with high content of gossypol on development of the cotton bollworm Heliothis armigera (Hbn.) (Lepidoptera: Noctuidae). J. Econ. Entomol. 68:129-137. 
حساسية ست أصناف وطرز من القطن للاصابة بدودة اللوز القرنفلية خلال الموسم فى محافظة كفرالثيخ ، مصر حسن محمد حسن صومع وجمال محمد محمود زايد

\section{معهل بحوث وقاية النباتات ـ مركز البحوث الززاعية ـ الدقى ـ مصر}

أجريت هذه التجارب خلال موسمي القطن 2012 ، 2013 في مزرعة محطة البحوث الزراعية بسخا ، محافظة كفرالثيخ بهدف دراسة

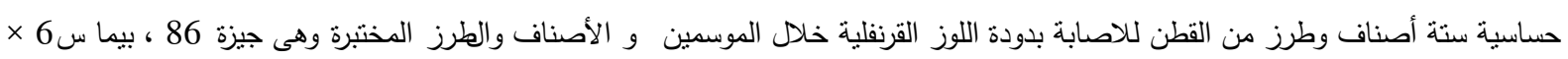

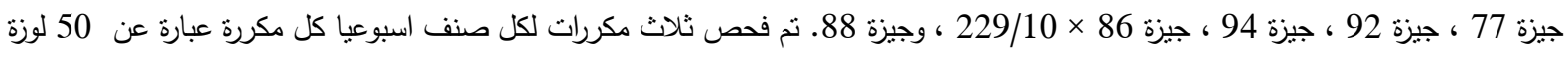

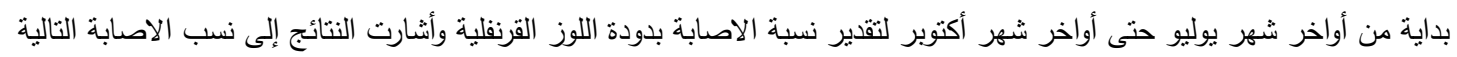

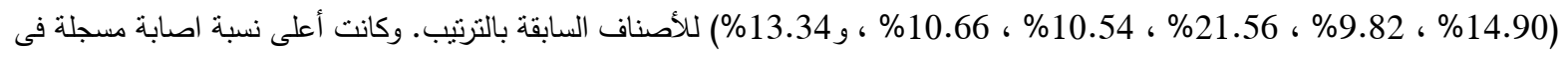

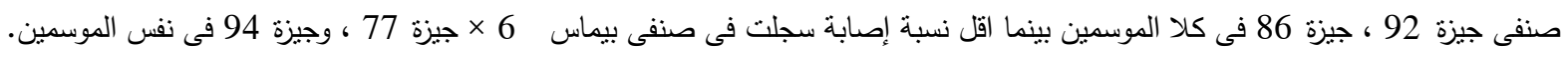

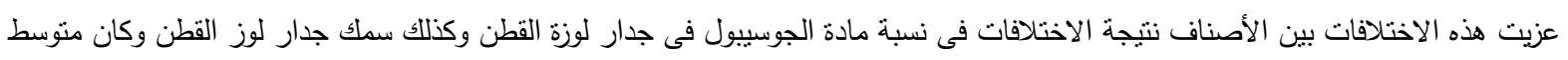

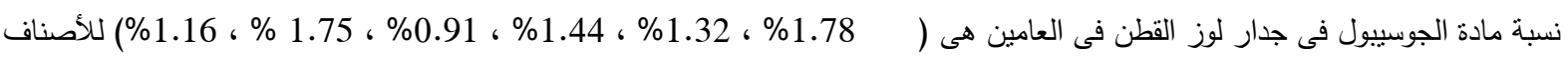

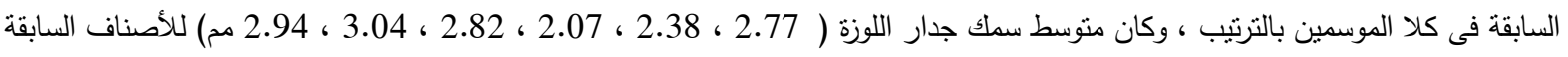

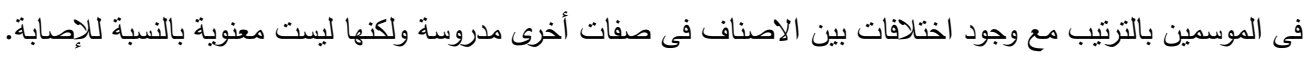

